\title{
sciendo
}

\section{Assessing Tourist Revisit Intention through the Sports and Recreational Services Offered}

\author{
Zarko Markus \\ University of Montenegro, Faculty for Sport and Physical Education, Nikšić, \\ Montenegro \\ Djurdjica Perovic, Sanja Pekovic \\ University of Montenegro, Faculty of Tourism and Hotel Management, Kotor, \\ Montenegro \\ Stevo Popovic \\ University of Montenegro, Faculty for Sport and Physical Education, Nikšić, \\ Montenegro
}

\section{Abstract}

Background: Sports and recreational tourism are forms of tourism that imply active involvement of tourists in various sports activities during their vacation, and it can be said that the main motive of such a vacation is a sport. Objectives: This research aimed to determine the relationship between sports and recreational activities and tourist satisfaction based on the questionnaire related to the behaviour and satisfaction of tourists during their stay in Montenegro. Methods/Approach: Regression analysis has been conducted in order to assess the interaction between sport-recreational activities and previous experience in Montenegro, and their effect on tourist revisit intention. Results: Empirical results demonstrate the influence of sports and recreational services on tourist satisfaction measured by tourists' revisit intentions. Distinguishing between sports, and health, spa and wellness facilities and services, the findings indicate that health, spa, and wellness facilities and services have a higher impact on revisit intention than sports activities. In addition, the interaction effect between different sports and recreational activities and previous experience in Montenegro did not provide a more amplified effect on tourist satisfaction. Conclusions: Establishing closer links between workers who provide sports services and those providing other tourist services is one of the main challenges in the future of the development of sports tourism in Montenegro, as one of the most critical aspects that can provide tourist satisfaction. The data study can be used for more efficient and effective decision making and strategy development of sports and recreational activities in the tourism industry.

Keywords: sport, recreational, tourism, satisfaction, revisit intention

JEL classification: M21

Paper type: Research article

Received: Sep 20, 2018

Accepted: Nov 25, 2018

Citation: Markus, Z., Perovic, Dj., Pekovic, S., Popovic, S. (2019), "Assessing Tourist Revisit Intention Through the Sports and Recreational Services Offered", Business Systems Research, Vol. 10, No. 2, pp. 141-150.

DOI: 10.2478/bsrj-2019-023 


\section{Introduction}

From the earliest stages of tourism development, sport-recreational activities have had an outstanding role, share, and importance in designing and defining tourist services and facilities. The departure of people from their place of residence is often associated with various sporting events to which they travel. In contemporary tourism, the sport has an even more critical role, and the relationship between sport and tourism is considered a separate industry (Jajić, Tišma and Perić, 2015). Tourism is most often viewed as a human need arising from a modern lifestyle, which, like sport, is characterized by a specific need to be active, participating, and engaging. Sports tourism conceives sport as being a tourist attraction that contributes to the attractiveness and quality of the tourist destination. Sports tourism is an economical, social, political, and cultural phenomenon, a combination of sport and tourism (Bull and Weed, 2009).

The definition of sport tourism depends on the aspect or mode of its perception, but it can be claimed that it represents any form of active or passive engagement in sport activity on an individual or organized basis, for commercial or non-commercial purposes, which conditions movement outside the place of permanent residence (Hinch, Jackson, Hudson and Walker, 2005, Kesar, 2012). Research shows that sports tourism is one of the world's largest tourism sectors (Gratton and Taylor, 2000).

The number of studies that analyse sport-recreational activities as a factor of tourists' satisfaction is not large. Therefore, this research analyses the most important aspects of sport and tourism activities (e.g., recreational sport, health, spa and wellness activities) and their role in creating the satisfaction of tourists, referring to the results of several authors dealing with similar topics: (i) on sports tourism (Gibson, 2005; Bull and Weed, 2004); (ii) correlation between sporting events and destination management (Kaplanidou and Vogt, 2007); (iii) on the motivation and satisfaction of a sportsman on the example of a specific kind of tennis, (Ramírez-Hurtado and Paralera-Morales, 2014); and (iv) on the behaviour and consumption of sports tourists (Gammon and Robinson, 2003).

The main goal of this paper is to investigate the extent to which sport-recreational activities influence the creation of tourist satisfaction. To our knowledge, only Markuš et al. (2017) examine similar relationships. Therefore, we extend our work using revisit intention as a measure for tourist satisfaction. In addition, we examine the interaction between sport-recreational activities and previous experience in Montenegro, their effect on tourist revisit intention. In this way, this pilot analysis should enable a better understanding of the given phenomena and establish the preconditions for making more comprehensive, more complete, and detailed research papers on this topic. Furthermore, the empirical evidence obtained on the example of Montenegro will also be relevant in the context of understanding the mechanisms of creating the satisfaction of tourists visiting Montenegro through sports activities, and therefore applicable in practice. The data study will provide a clear insight into the given correlation and, as such, can be used for more efficient and effective decision making and strategy development of sport and recreational activities in the tourism industry.

\section{Literature review}

Recreational tourism activities can enable hotels to improve the overall expectation of guests and thus improve their satisfaction. Therefore, most hotels strive to increase the diversity and quality of recreational activities that are mainly dependent on the size and standards, the availability of qualified hotel staff, as well as its location. The diversification of hotel facilities in the sector of sport and recreational activities aims at 
a better and more complete tourist experience, a higher level of satisfaction, and a creation of an offer that will be more competitive than other similar products. In the past, the direction of diversification was based on traditional active forms of leisure (e.g., various sports, tennis, swimming, gymnastics, running, etc.), so the hotel and infrastructure in the destination followed this trend through the construction of sport grounds, green recreation areas, indoor terrains, covered areas, and others.

A more modern approach to the development of hotels and destinations in the part of active holidays is towards more current forms of tourism facilities and services. On the one hand, there are rehabilitation and recreational facilities (e.g., spa, gym, fitness, aerobics, etc.), and on the other, more creative forms combine recreational activities with other activities (such as orienteering, hiking). However, empirical analyses of causal links between sport and recreational activities, satisfaction, and the return of tourists are very limited.

In a 2016 study, Cheng and Tsai analyse the habits of Taiwanese tourists, and they infer that for all sport tourist activities, the main factor determining the satisfaction of the tourists with the activity in which they participated was the process of having different experiences (e.g., interactions that create stronger links between tourists, relaxation, stress relief, increased physical strength and flexibility, trust in the instructor). The indicated example shows the significance of the programme of active stay of tourists such as "team building," where through the moderate physical activity a goal is achieved, but above all, through the building of team spirit and togetherness. There is no doubt that putting sport and recreation into the context of modern business tourism provides new opportunities for the development of innovative facilities and services of hotels and destinations.

Analysing tourists visiting the Sun Moon Lake Swimming Carnival Event, Yeh, Hua, and Huang (2016) have shown that improving the quality of the sports programme will result in significant economic improvements.

Stanovcic, Pekovic, Celebic, and Simovic (2015) analysed how sport-recreational activities affect the consumption of tourists during their stay in Montenegro. Their results imply that the so-called continental sports activities (i.e., those typical of dominantly mountainous areas in the interior of Montenegro) positively influence the spending of tourists while water sport activities are not related to such consumption. The above can be interpreted in such a way that water sports represent an integral part of bathing tourism and the offer of "sun and sea", and therefore have no decisive or significant impact on total consumption, i.e., do not affect the change due to changes in the offer of the mentioned contents. In contrast, the continental activities have a positive impact on consumption because they are an underlying attraction of the holiday or a holiday package.

Using statistical analysis of data on the perceived value, quality, satisfaction, and loyalty of tourists to sport and tourist destinations, Jalilvland et al. (2014) indicates that the perceptions of the quality of services and the value of the sport tourist destination had a positive direct and indirect impact on loyalty and tourist satisfaction.

Based on the previous discussion that points out that sport and recreational activities in catering can enable hotels to increase the overall satisfaction of guests:

- H1 - A statistically significant positive correlation is expected between the tourist satisfaction and the offer of sport-recreational facilities and services. 


\section{Methodology}

\section{Database}

The data used are part of the survey called "Guest Survey" carried out in Montenegro in 2010. The survey was conducted by the Ministry of Tourism of Montenegro, the National Tourism Organization of Montenegro, and the German Technical Cooperation Organization (GTZ). The main goal of the research is to obtain a representative view of the tourist behaviour and their satisfaction during their stay in Montenegro. The questionnaire contains 34 questions, and it is translated into seven languages (Montenegrin, English, French, Italian, Albanian, German, and Russian). The survey was conducted in 21 municipalities in Montenegro, from July to the end of September 2010. The time allocated for tourists to fill in the questionnaire was not limited, but it took about 30 minutes. A total of 1442 tourists completed the questionnaire. Most of the tourists stayed in the south of the country (76.8\%), followed by the central part (16.9\%), and $6.2 \%$ of tourists were in the northern part of Montenegro. After deleting observations with incomplete information, we have a sample of about 1000 respondents.

\section{Variable description}

There were 14 questions related to the satisfaction of tourists, sport-recreational activities, and socio-demographic characteristics of tourists. The satisfaction of the tourists was measured through: [1] The return of tourists to Montenegro for a holiday in the next three years using a scale of values, which consists of four options: [a] definitely yes; [b] probably yes; [c] probably no; [d] definitely no.

[2] Sport and recreational activities are defined with two issues related to [a] sports facilities and services and [b] health, spa, and wellness facilities and services. Both issues related to sport-recreational activities are defined by a value scale, which consists of four options: [a] very satisfied; [b] satisfied; [c] less satisfied; [d] not satisfied.

Furthermore, nine additional questions were used as control variables related to the socio-demographic characteristics of tourists: gender, age, the country from which the tourist arrives, employment, salaries, previous visits to Montenegro, number of overnight stays, type of accommodation and type of transport. Control variables usually vary, which we are not particularly interested in, but which relate to the dependent variable. In order to eliminate their effects on dependent variables, it was decided to include the following control variables used in previous studies with similar themes (e.g., Perović, Stanovčić, Moric and Peković, 2012; 2013): Gender: equal to 1 if the tourist is a man; Age: a continuous variable indicating the age of tourists; Four groups of countries from which tourists arrive are used: D1 represents Bosnia, and Herzegovina, Croatia, Macedonia and Serbia, D2 represents the EU countries, D3 = 1 if the tourist comes from the countries of the former Soviet Union and D4 $=1$ if the tourist comes from the rest of the world; The employment of tourists is identified through five binary variables: self-employment, employed in a private enterprise, working as a public official / public sector, a tourist is retired, and a tourist is a student; The level of personal income is also identified through three binary variables: $\mathrm{V} 1$ - monthly net household income is up to 900 euros, V2- monthly net income of households is between 900 and 3000 euros and V3- monthly net income of households is more than 3000 euros; Previous vacation visits to Montenegro is a binary variable; Number of overnight stays; Type of accommodation; Type of transport.

The sample statistics for the variables used are presented in Table 1. 
Table 1

Definition of Variables and Descriptive Statistics $(N=1,010)$

\begin{tabular}{|c|c|c|c|c|c|}
\hline Variables & Definition & SV* & SD** & Min & Max \\
\hline REVISIT & $\begin{array}{l}\text { Will you come back to Montenegro for } \\
\text { a holiday in the next } 3 \text { years? } \\
\text { (Ordinal Variable) }\end{array}$ & 3.360 & 0.65 & 1.00 & 4.00 \\
\hline $\begin{array}{l}\text { SPORT FACILITIES AND } \\
\text { SERVICES }\end{array}$ & $\begin{array}{l}\text { The pleasure of tourists with sports } \\
\text { facilities and services during their stay in } \\
\text { Montenegro (Ordinal variable) }\end{array}$ & 3.24 & 0.74 & 0.00 & 4.00 \\
\hline $\begin{array}{l}\text { HEALTH, SPA AND } \\
\text { WELLNESS OFFER }\end{array}$ & $\begin{array}{l}\text { The pleasure of tourists with health, spa } \\
\text { and wellness offer during their stay in } \\
\text { Montenegro } \\
\text { (Ordinal Variable) }\end{array}$ & 3.20 & 0.76 & 0.00 & 4.00 \\
\hline GENDER & $\begin{array}{l}\text { Gender of tourists: } \\
\text { Male gender }=1 \\
\text { (Binary variable) }\end{array}$ & 0.54 & 0.50 & 0.00 & 1.00 \\
\hline AGE & $\begin{array}{l}\text { Age of tourists } \\
\text { (continual variable) }\end{array}$ & 33.63 & 11.98 & 17 & 82 \\
\hline RESIDENCE & $\begin{array}{l}\text { Country and place of residence of } \\
\text { tourists: } \\
\text { (1) countries of ex-Yugoslavia } \\
\text { (2) the EU Member states } \\
\text { (3) countries of ex USSR } \\
\text { (4) rest of the world } \\
\text { (Binary variable) }\end{array}$ & $\begin{array}{l}0.61 \\
0.24 \\
0.12 \\
0.03\end{array}$ & $\begin{array}{l}0.49 \\
0.43 \\
0.32 \\
0.17\end{array}$ & $\begin{array}{l}0.00 \\
0.00 \\
0.00 \\
0.00\end{array}$ & $\begin{array}{l}1.00 \\
1.00 \\
1.00 \\
1.00\end{array}$ \\
\hline EMPLOYMENT & $\begin{array}{l}\text { Employment of tourists: } \\
\text { (1) freelancing/self-employment } \\
\text { (2) employed by the company } \\
\text { (3) civil servant/official } \\
\text { (4) pensioner } \\
\text { (5) student } \\
\text { (6) unemployed (e.g., I run a household) } \\
\text { (Binary variable) }\end{array}$ & $\begin{array}{l}0.20 \\
0.41 \\
0.05 \\
0.06 \\
0.25 \\
0.03\end{array}$ & $\begin{array}{l}0.40 \\
0.49 \\
0.22 \\
0.24 \\
0.43 \\
0.18\end{array}$ & $\begin{array}{l}0.00 \\
0.00 \\
0.00 \\
0.00 \\
0.00 \\
0.00\end{array}$ & $\begin{array}{l}1.00 \\
1.00 \\
1.00 \\
1.00 \\
1.00 \\
1.00\end{array}$ \\
\hline REVENUES & $\begin{array}{l}\text { Monthly income of tourists per } \\
\text { household: } \\
\text { (1) up to } 900 \text { euros } \\
\text { (2) between } 900 \text { and } 3,000 \text { euros } \\
\text { (3) more than } 3,000 \text { euros } \\
\text { (Binary variable) }\end{array}$ & $\begin{array}{l}0.14 \\
0.52 \\
0.34\end{array}$ & $\begin{array}{l}0.45 \\
0.50 \\
0.47\end{array}$ & $\begin{array}{l}0.00 \\
0.00 \\
0.00\end{array}$ & $\begin{array}{l}1.00 \\
1.00 \\
1.00\end{array}$ \\
\hline EARLY VISIT & $\begin{array}{l}\text { An earlier visit of a tourist in Montenegro } \\
\text { (Binary variable) }\end{array}$ & 0.67 & 0.47 & 0.00 & 1.00 \\
\hline $\begin{array}{l}\text { NUMBER OF } \\
\text { OVERNIGHT STAYS }\end{array}$ & $\begin{array}{l}\text { Number of tourists' overnight stays in } \\
\text { Montenegro } \\
\text { (Ordinal variable) }\end{array}$ & 2.96 & 1.51 & 1.00 & 7.00 \\
\hline \multirow[t]{4}{*}{ ACCOMMODATION } & $\begin{array}{l}\text { Type of accommodation of tourists } \\
\text { during their stay in Montenegro } \\
\text { (1) hotel/board/guest house }\end{array}$ & & & & \\
\hline & (2) private accommodation/suite & 0.38 & 0.48 & 0.00 & 1.00 \\
\hline & $\begin{array}{l}\text { /room/bungalow/mountain hut/ } \\
\text { camp/etc. }\end{array}$ & 0.45 & 0.50 & 0.00 & 1.00 \\
\hline & $\begin{array}{l}\text { (3) apartment / holiday house / at } \\
\text { friend's / cousin's } \\
\text { (Binary variable) }\end{array}$ & 0.17 & 0.37 & 0.00 & 1.00 \\
\hline \multirow[t]{5}{*}{ TRANSPORT } & $\begin{array}{l}\text { Type of transport of tourists to come to } \\
\text { Montenegro }\end{array}$ & & & & \\
\hline & Plane & 0.35 & 0.37 & 0.00 & 1.00 \\
\hline & Bus & 0.25 & 0.43 & 0.00 & 1.00 \\
\hline & Car & 0.31 & 0.46 & 0.00 & 1.00 \\
\hline & $\begin{array}{l}\text { Train } \\
\text { (Binary variable) }\end{array}$ & 0.09 & 0.29 & 0.00 & 1.00 \\
\hline
\end{tabular}

Source: Authors' work

Note: * Medium value; ** Standard deviation 


\section{The empirical model}

Since in this paper, the first dependent variables are censored with an upper limit of 1 , the Tobit regression model is an adequate econometric technique for determining the relationship between sport-recreational activities and re-visit to Montenegro. The Tobit model expresses the dependent variable in relation to latent variables:

$$
\begin{gathered}
Y^{*}=\beta_{0}+x_{\beta}+u, u \mid x \sim \operatorname{Normal}(0,) \\
Y=\max \left(0, y^{*}\right)
\end{gathered}
$$

All statistical analyses were done using the "Stata 14" software package.

\section{Results}

The results of Tobit models related to the return of tourists to Montenegro are shown in Table 2.

\section{Table 2}

\begin{tabular}{|c|c|}
\hline Variables & Coefficient and statistical significance \\
\hline Constant & $2.27^{* * *}$ \\
\hline SPORT FACILITIES AND SERVICES & $0.08^{* * *}$ \\
\hline $\begin{array}{l}\text { HEALTH, SPA AND WELLNESS FACILITIES AND } \\
\text { SERVICES }\end{array}$ & $0.13^{* * *}$ \\
\hline GENDER & -0.03 \\
\hline AGE & 0.00 \\
\hline RESIDENCE & \\
\hline (1) countries of ex-Yugoslavia & Reference \\
\hline (2) the EU Member states & $-0.12^{* *}$ \\
\hline (3) countries of ex USSR & -0.04 \\
\hline (4) rest of the world & $-0.27^{* *}$ \\
\hline EMPLOYMENT & \\
\hline (1) freelancing / self-employment & 0.05 \\
\hline (2) employed by the company & Reference \\
\hline (3) civil servant / official & -0.11 \\
\hline (4) pensioner & -0.10 \\
\hline (5) student & -0.02 \\
\hline (6) unemployed (e.g., I run a household) & $0.19^{*}$ \\
\hline REVENUES & \\
\hline (1) up to 900 euros & -0.00 \\
\hline (2) between 900 and 3,000 euros & Reference \\
\hline (3) more than 3,000 euros & -0.05 \\
\hline EARLY VISIT & $0.27^{* * *}$ \\
\hline NUMBER OF OVERNIGHT STAYS & $0.04^{* * *}$ \\
\hline ACCOMMODATION & \\
\hline (1) hotel/board / guest house & -0.03 \\
\hline (2) private accommodation/suite/ & -0.09 \\
\hline (3) apartment/holiday house/at friend's/cousin's & Reference \\
\hline TRANSPORT & \\
\hline (1) Plane & $0.14^{*}$ \\
\hline (2) Bus & $0.16^{* * *}$ \\
\hline (3) Car & $0.16^{* * *}$ \\
\hline (4) Train & Reference \\
\hline
\end{tabular}

Results of the Tobit Model - Re-Visit in Montenegro

\section{Source: Authors' work}

Note: $\left({ }^{*}\right),\left({ }^{* *}\right),\left({ }^{* * *}\right)$ indicate the meaning of the parameter at the level of 10,5 , and 1 per cent, respectively. 
The results of the analysis confirm that there is a statistically significant influence of the independent variable on the dependent variable. In this way, the results point to the conclusion that sport-recreational activities have a positive impact on the return of tourists to Montenegro. The reasons for this result can be explained by the advanced state of development of the well-being spa and wellness services and facilities in most high-class hotels, as this is an irreplaceable element of their offers, as well as a categorization criterion according to national legislation. Knowing that these contents are usually developed and available, it is understandable that they determine the positive impression of the hotel as well as the overall destination. In contrast, other sport and recreation facilities and services, especially those that are realized outside the hotel context, are less developed in Montenegro. This weakness is reflected in the infrastructural sense (e.g., lack of open and closed terrain and space for various sports); difficulties in organizing these activities in a wider area, i.e., nature, due to higher costs and lack of skilled labor; insufficient general development of sport tourism and relatively smaller number of sport tourists in the total number of tourists in Montenegro, etc. These data and results represent a significant developmental guide for managers at all levels of tourism management in Montenegro, that in the future the priorities of development of sport tourism and the development of sport and recreation as additional content in other forms of tourism should be redefined (e.g., bathing, MICE and the like).

Regarding the control variables, we have statistically significant positive coefficients for the previous visit, the number of overnight stays, and transportation, which indicates their importance for the return of tourists to Montenegro.

\section{Interaction effect}

As our findings reveal that previous experience in Montenegro has a significant influence on our dependent variables, we want to investigate whether the interaction between sport and health, spa and wellness activities would have amplified effect on tourist satisfaction.

Following Aiken and West (1991), we mean-centre the sport-recreational activities variables prior to calculating the interaction terms in order to reduce potential multicollinearity concerns and enhance the interpretation of the results. The summary of the main results is presented in Table 3.

Table 3

Results of the Tobit Model - Revisit in Montenegro/Interaction Effect

\begin{tabular}{lc}
\hline VARIABLES & COEFFICIENT AND STATISTICAL \\
Constant & SIGNIFICANCE \\
\hline Interaction effect & $2.10^{* * *}$ \\
Sports facilities and services & $0.10^{* * *}$ \\
Health, spa and wellness facilities and services & $0.10^{* * *}$ \\
\hline SO & $0.15^{* * *}$ \\
\hline
\end{tabular}

Source: Authors' work

Note: $\left({ }^{*}\right),\left({ }^{* *}\right),\left({ }^{* * *}\right)$ indicate the meaning of the parameter at the level of 10,5 , and 1 per cent, respectively.

Table 3 demonstrates findings that suggest that interaction between sportrecreational activities has a positive and significant effect on revisit intent; however, the coefficient of the interaction term is lower than the coefficient of the health, spa and wellness activities variable. 


\section{Conclusion}

This research has analysed whether different types of sport-recreational activities affect the return to the destination. Using empirical analysis, we have established that sports facilities and services as well as health, spa and wellness facilities and services positively influence the return of tourists. In addition, there is a positive impact on the return of on-the-spot and generating new tourist visits with probable significant economic benefits. The emphasis on the role of the spa, wellness, and other hotel amenities in the recreation and physical activity segment draws attention to the fact that these types of services and facilities have managed to occupy an essential place in the perception of consumers and certainly positively affects the overall image of the hotel and destination. It is noteworthy that the interaction effect between sportrecreational activities did not have a beneficial effect on tourist satisfaction compared to the effect of the activities alone. The findings suggest that managers and policy-makers make additional efforts to create a better environment that would support synergy between those activities. New investments, strategic decisions at macro-levels of governance, legal frameworks, and a more favourable business environment make it necessary to compensate and develop the disadvantages in the sport-recreational sector to the level that can generate higher consumption and new jobs. Therefore, it can be concluded that the results of this research provide a number of practical guidelines and ideas for the further development of sport tourism in Montenegro.

Although a number of tourism entities have various programmes involving physical activities and extreme sport in their offers, Montenegro does not have a clearly defined strategy for the development of sport tourism at the local or national levels. Considering the potential of the Montenegrin coastal and mountain area for dealing with various sports, as well as existing infrastructure facilities and sports trainers, it is clear that there are conditions for the more significant development of sport tourism. To encourage the development of sport and tourism in Montenegro, workers in that sector must act together to achieve tourist satisfaction. In that direction, it is necessary to improve the content, diversity, and quality of the facilities and services, adjust working hours to the needs of guests, continuously network sport and tourist facilities and associations, etc. At the destination level (e.g., local, regional or national administration), it would be significant to create a unique strategy for the development of sport tourism, which, with precise identification of the opportunities, challenges, advantages, and disadvantages of sport and tourism products and services on the Montenegrin market, would enable better networking of sport and tourism entities and encourage their joint action towards the development of this form of tourism.

Therefore, the establishment of closer links between the organizers of sports events, tourist workers, and local self-government is one of the main challenges in the future development of sport tourism in Montenegro. To provide more social and economic benefits at the local level and provide a satisfactory service to visitors to a sports event, they need to be better coordinated and integrated (Hudson, 2012; Pekovic, Perovic, Stanovcic and Vukcevic, 2018). 


\section{References}

1. Aiken, L. S., West, S. G. (1991), Multiple regression: Testing and interpreting interactions, Sage, Newbury Park.

2. Bull, C., Weed, M. (2009), Sport Tourism: Interrelationships, Impacts and Issues, Elsevier, Oxford.

3. Bull, C., Weed, M. (2004), Sports Tourism: Participants, Policy and Providers, Elsevier, Oxford.

4. Cheng, T. H., Tsai, C. G. (2016), "Female listeners' autonomic responses to dramatic shifts between loud and soft music/sound passages: a study of heavy metal songs", Frontiers in Psychology, Vol. 7, p. 182.

5. Gammon, S., Robinson, T. (2003), "Sport and Tourism: A conceptual Framework", Journal of Sport \& Tourism, Vol. 8, No. 1, pp. 21-26.

6. Gibson, H. (2005), Sport Tourism: Concepts and Theories. An Introduction, Taylor and Francis publications, UK.

7. Gratton, C., Taylor, P. (2000), Economics of Sport and Recreation, E. \& F.N. Spon., London.

8. Hinch, T., Jackson, E. L., Hudson, S., Walker, G. (2005), "Leisure Constraint Theory and Sport Tourism", Sport in Society, Vol. 8, No. 2, pp. 142-163.

9. Hudson, S. (2012), Sport and adventure tourism, Routledge, London.

10. Jajić, J., Tišma, S., Perić, D. (2015), "Značaj fitnes kampova za razvoj sportskog turizma", Tims. Acta: naučni časopis za sport, turizam i velnes, Vol. 9, No. 2, pp. 179-187.

11. Jalilvland, M. R., Pool, J. K., Vosta, L. N., Nafchali, J. S. (2014), "The effect of marketing constructs and tourists' satisfaction on loyalty to a sport destination: A structural equation model and analysis", Education, Business and Society: Contemporary Middle Eastern Issues, Vol. 7, No. 4, pp. 316-332.

12. Kaplanidou, K., Vogt, C. (2007), "The interrelationship between sport event and destination image and sport tourists' behaviours", Journal of Sport \& Tourism, Vol. 12, No. 3-4, pp. 183206.

13. Kesar, O. (2012), Sportski turizam. Ekonomski fakultet. Sveučilište u Zagrebu.

14. Markuš, Z., Peković, S., Popović, S. (2017), "The Role of Sport-Recreational Activities in Creation of Tourism Satisfaction", in proceedings of the 7th International Scientific Conference-Knowledge and business challenges of globalization, Celje, Slovenia, pp. 367373.

15. Pekovic, S., Perovic, Dj., Stanovcic, T., Vukcevic, J. (2018), "Is Montenegro Considered as a Sports-Recreational Destination?", Sport Mont, Vol. 16, No. 2, pp. 83-86.

16. Perović, Đ., Stanovčić, T., Moric, I., Peković, S. (2012), "What socio-demographic characteristics do influence the level of tourist's satisfaction in Montenegro? Empirical analysis", Revista de Tourism - studii si cercetari in turism, Vol. 14, pp. 5-10.

17. Perović, Đ., Stanovčić, T., Moric, I., Peković, S. (2013), "What factors influence quality service improvement in Montenegro: Empirical analysis", International Journal for Quality Research, Vol. 7, No. 1, pp. 63-70.

18. Ramírez-Hurtado, J. M., Paralera-Morales, C. (2014), "Assessing motivation and satisfaction in an emerging kind of sports tourism: paddle tennis", Enlightening Tourism: A Pathmaking Journal, Vol. 4, No. 2, pp. 168-194.

19. Stanovcic, T., Pekovic, S., Celebic, A., Simovic, O. (2015), "Tourism expenditure for sport activities: the case of Montenegro", Sport Mont, Vol. 13, No. 43-44-45, pp. 239-244.

20. Yeh, C. C., Huo, K. T., Huang, C. H. (2016), "Service quality improving effects and recreational benefits for sports tourism-A case study", Tourism Economics, Vol. 22, No. 6, pp. $1332-1337$. 


\section{About the authors}

Zarko Markus obtained his Master degree from the University of Montenegro in the field of sport management. He presented at several academic conferences i. and participated in a number of European training and programs. The author can be contacted at zarko.markus@yahoo.com.

Djurdjica Perovic, Ph.D., has been a Professor at the Faculty of Tourism and Hotel Management of the University of Montenegro since 2008. She defended her thesis "The state and directions of tourism development of the Montenegrin coast in the function of a successful market appearance" at the Faculty of Science and Mathematics of the University of Novi Sad. She has been the Vice Rector at the University of Montenegro since December 2017. Previously she was the Dean of the Faculty of Tourism and Hospitality since 2013. Her research fields are Tourism, Tourist Regions, Cultural Tourism and Selective Forms of Tourism. She has published more than 30 papers and she has participated at more than 20 science conferences. She is the author and co-author on two monographs. She has experience in Heric, IPA, Erasmus+ and bilateral projects. She was a visiting professor at "MESI" University and Russian New University from Moscow. The author can be contacted at duda@ac.me.

Sanja Pekovic holds a Ph.D. in Economics from the University Paris-EST. She is an Assistant Professor at the Faculty of Tourism and Hotel Management. Since October 2017, she is Director of Centre for Quality Assurance of UoM. She is a member of the University Senate. Between 2006 and 201 1, she was Researcher at the Center for Labor Studies (Centre d'Eudes de l'Emploi) and Lecturer at the University Paris-EST. Her research interests are within the field of quality and environmental economics, the economics of innovation, applied econometrics, and on this topic, she has presented studies at national and international scientific congresses, which have been published in international journals. Dr Pekovic was visiting scholar at the INRASupArgo (Montpellier), at the University of Montenegro (Podgorica), at the Laboratoire CNRS UMI 2615 Franco-Russe PONCELET (Moscow) and at Institute of Environment, UCLA (LOS Angeles), etc. The author can be contacted at psanja@ac.me.

Stevo Popovic holds a Ph.D. in Sports Science from the University of Novi Sad, while he has completed his postdoc at the University of Ljubljana in the same scientific field. He is an Associate Professor at the Faculty for Sport and Physical Education at the University of Montenegro. Since May 2015, he is a Dean of the Faculty for Sport and Physical Education. He is an Editor-in-Chief of University of Montenegro Press, as well as co-director of Balkan Institute of Science and Innovation at the University. His research interests are within the field of anthropology of sport and physical education, the leadership of sport and social issues of sport, and on this topic, he has presented studies at national and international scientific congresses, which have been published in international journals too. He was visiting scholar at many European universities through CEEPUS and Erasmus+ programmess: University of Ljubljana, Université Nice Sophia Antipolis, University of Split, Aristotle University of Thessaloniki, University of Novi Sad, etc. He is a member of the Center of Young Researchers within Montenegrin Academy of Science and Art. The author can be contacted at stevo.popovic@ucg.ac.me. 